\title{
A Historical and Econometric Analysis of Energy Consumption and Industrial Output in Pakistan (1990-2019)
}

\section{Muhammad Umair}

Lecturer

Department of Economics

Emerson University Multan

umquaidian@gmail.com

\section{Muhammad Ramzan Sheikh}

Associate professor

School of Economics

Bahauddin Zakariya University, Multan

ramzansheikh@bzu.edu.pk

\author{
Kashif Saeed \\ Assistant professor \\ Department of Accounting and Finance, \\ The Islamia university of Bahawalpur \\ kashif.saeed@iub.edu.pk
}

\begin{abstract}
This paper examines the nexus of disaggregated energy consumption and industrial output in Pakistan. The annual time series data over the period 1990-2019 has been taken for current research. ARDL technique has been employed for empirical analysis. The results show that oil consumption, electricity consumption and gas consumption are positively and significantly connected with the industrial output in long run. Similarly, trade openness, labour and capital also have the same association with the industrial output and have significant outcomes in the long run. The results of Granger causality show that there exists a unidirectional causality from electricity consumption to industrial output. The study concludes that oil, gas and electricity are contributing a large share in industrial growth so that it would be made an effort to install the plants relevant with these energy sources to meet the affordable demand in the industry sector.
\end{abstract}

Keywords: Energy Consumption, Annual Energy Trends, Industrial Sector Output

(C) 2021 The Authors, Published by The Women University Multan. This is an Open Access Article under the Creative Common Attribution Non-Commercial 4.0
Date of Acceptance: 01 December 2021 Available Online: 28 December 2021 


\section{Introduction}

Energy is so vital element for the progress of industrialization and economic development. It is directly related to the output level of industry that improves the lifestyle of masses with having highincome level, jobs and wealth. It is because of high thruput and profitability in the industry sector that today many nations like Pakistan are moving towards economic development. Primarily, Industrialization is a long-run phenomenon that improves the welfare of society, reduces the unemployment level (Abdu and Anam, 2018). The advanced mechanization in technology and economic diversification is also the result of long-run industrial development. Though electricity, fuel consumption, gas i.e., are the important indicators that are needed to derive the plants, machinery and other instruments connected with this sector (Tapsin, 2017). Recently a large number of innovations and discoveries in the world is due to advance mechanization in the energy sector that further intensifies the economic growth as well as economic development of any nation. Likewise, the dependency rate of human activities is now more interconnected with the energy sector. Though inexpensive and reliable energy is a fundamental need for the inventions of the industrial as well as economic structure. The energy demand is increasing day by day in many developing countries including Pakistan because of expansion in the industry sector and due to the usage of modern tools in the production process. But the inappropriate investment in domestic resources is a big gap for creating dependency on importable energy. In addition, the less investment and low concentration on lignite, natural gas and hydro related energy generate a severe obstacle in the process of industrial development (Kassim and Isik, 2020). Though energy is a chief indicator for escalating the economic growth as well as for intensifying the structural framework of nations. There has been observed a shortage of energy from a few years ago because of increasing the demand side while the shortage of energy supply sources. The world population, technology, industrialization, huge amount of urbanization and modernization are key factors that cause energy crises today in many countries including Pakistan that is also facing a great challenge due to the shortage of energy. In addition, a recent report of the UN indicates that the present population of the world is nearly 7.6 billion that is predicted to increase by 8.6 billion 
by 2030 , and similarly, it will increase by nearly 9.8 billion in 2050 . In addition, it will increase by virtually 11.2 billion by $2100^{i}$. The main contributors in this repute will be African and many Asian countries for the increasing population (Akbar et al. 2021). Pakistan is a developing country with having strong economic growth, but no efforts have been done by ruling parties until the moment after independence to ensure the capacity building in energy infrastructure or to tackle the demand side of energy. However, it has been attempted to analyze the specific energy consumption effects on industrial output that is considered a domineering pillar for industrialization and economic development as the study of Tapsin (2017), Theophilus et. (2016), Yahaya et al. (2015) used disaggregate energy consumption for measuring the industrial output in their research. Santas and Sari (2003) also used disaggregate energy consumption data for analyzing the Turkey and Taiwan economies found significant outcomes using electricity and income level of manufacturing sector data. The aggregated energy data is not proficient to measure the overall economies or any sector output due to having different country infrastructure and different energy resources Yang (2000) and Nasir et al. (2021).

Though, following Yang (2000) and Nasir et al. (2021) current study has also used disaggregate energy consumption data for analyzing the industrial output performance of Pakistan. A study by Abid and Sebri 2012 reveals that the disaggregated energy data is prolific for observing the industrial output as compared to aggregate energy consumption that is not prolific for analyzing specific energy effects on the output level of industry because of the different structural framework of economies. The existing study is so different from other studies because of uses different data set, techniques, modelling and country analysis. Some of the studies have used aggregate energy analysis as studies Belloumi (2008), Tsani (2010), Gross (2012) while contrary some of the studies have used disaggregate energy analysis as study of Ziramba (2009) Hunt (2019), Sriyana (2019) and Nasir et al. (2021) showed different data set of energy with different time and techniques in their work. So, the present study has used data over the period 1990-2019 and used Autoregressive Distributed Lag (ARDL) technique. In addition, Granger causality has also been checked for analyzing the energy- 
Industrial output nexus in the short run. The different trends structures related to disaggregate energy consumption and industrial output are shown in the next segment.

\section{Trends and Size of Energy Consumption in Pakistan}

The energy demand is escalating day by day in Pakistan due to the usage of new mechanisms related to modern technology in the industry sector. The share of electricity consumption has also been increased from a few years ago because of installing numerous plants corresponding to previous years. The electricity consumption has been increased $26.3 \%$ from $25.5 \%$ in the previous year. Figure 1 shows the trends of total electricity consumption in the industrial sector over the period 1990-2019. The average value of electricity consumption (in Giga watt-hour) seems 12527.27 during the 19902000 period. While it has increased corresponding to last decade with the average value 18923.7 during 2000-2010 and with average value 25052 over the period 2011-2019 respectively in the industry sector. The percentage change in electricity consumption is seemed $25 \%$ during the first two decades of the current study due to increased demand in the industry sector.

\section{Figure 1: Electricity Consumption in Industry (Gwh)}

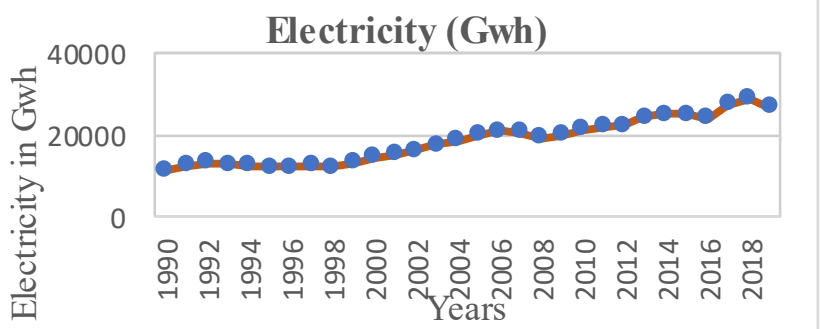

Source: Pakistan Economic Survey (various issues)

However, it seems with $13 \%$ in next two decades of study. The maximum value of electricity consumption is approximately 28760 of the industry sector in 2018 due to the usage of advanced mechanisms in the industry sector, while the minimum value is almost 11229 in 1990.

Gas is one of the leading sources of energy consumption for a few years which promptly upsurge economic activities. The trends of gas consumption have a positive silhouette over the study period 19902019 in Figure 2. The average value of gas consumption (in mmcft) 
in the industry sector is 111262.6 which has an increasing trend till 2009 in the second decade with an average value of 258808.3. However, it has decreasing trend till the mid-third decade 20102019 due to the volatility in the price level.

Figure 2: Gas Consumption in Industry (mmcft)

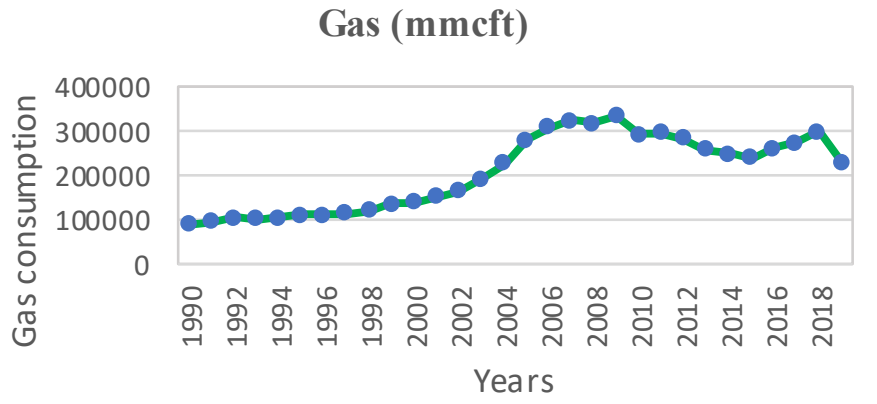

Source: Pakistan Economic Survey (various issues)

The maximum value of gas consumption (million cubic feet) in the industry sector is observed at 333508 during the period 2008-09, while the minimum value of gas consumption is 88841 in 1990 . Though the percentage change of gas consumption in the industry sector during the early twice decades of study is approximately $133 \%$ and it is almost $3 \%$ during the last two decades but overall, the trends have a positive silhouette. It has been observed that the extensive gas network has been erected because of excessive demand for gas that provides approximately 17.08 billion today for infrastructure especially in Liquefied Petroleum Gas (LPG).

\section{Figure 3: Oil Consumption in industry}

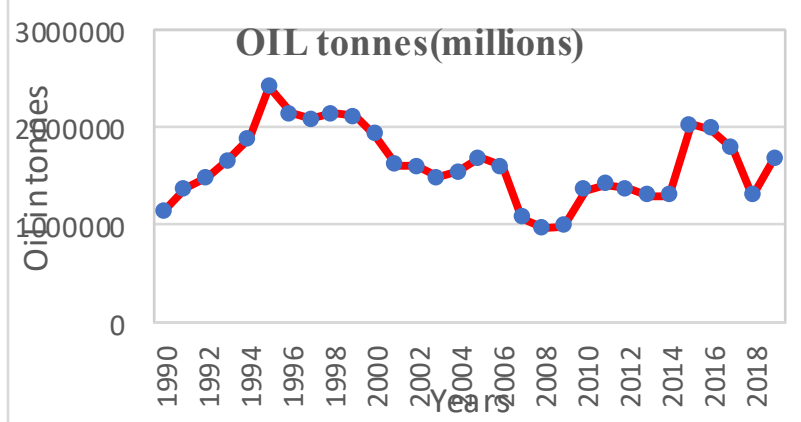

Source: Pakistan Economic Survey (various issues) 
Figure 3 shows the trends of oil consumption (million tonnes) in the industry of Pakistan during the period 1990-2019. It has a positive trend from 1990 to 1995 but after that, the oil consumption trends show that there is a sharp decline because of volatility in world prices. The average value of oil consumption is observed 850766 million tonnes in first decade 1990-2000, and it is 1390956 during the period 2000-2010 with the percentage change of $25 \%$ in last decade. Furthermore, the average value is amplified by 1576109 million tonnes during the $2010-2019$ period with the percentage change of $13 \%$ from last decade. However, the maximum value of oil consumption is seemed 2416278 million tonnes in 1995 , whereas the minimum value is 969193 during the period 2008-09. Electricity, gas and oil consumptions are the chief indicators of energy consumption that stimulate the industry output and economic activity progressively. A critical literature review on energy consumption and industrial output is discussed in the next part.

\section{Literature Review}

Numerous studies have been done to verdict the nexus between energy consumption and industrial output. Olufemi (2015) examined a study on disaggregate energy consumption and industrial output in Nigeria using the annual time series data over the period 1980-2012. The cointegration results found a positive and significant association between electricity consumption and industrial output in long run. The contrary result was found in the study of Nwajinka (2013) that showed that disaggregate energy consumption does not have any strong association with industrial output in Nigeria. The study of Biodun (2011) found a positive association of energy with industrial development. Similarly, the study of Nawaz et. al (2021) also revealed a significant effect of energy consumption and industrial output in developing countries. The findings of their study further reported a substantial effect of energy on economic growth. Akiri et al. (2015) examined a study on electricity supply and manufacturing output using the annual time series data over the period 1980-2012 and found a significant association between energy and manufacturing output. Likewise, Thoma (2004) presented a study on energy consumption and macroeconomic performance using the United States data over the period 1973-2000. The findings of the study verify the existence of 
macroeconomic changes that caused to stimulus the electricity influence in households, industry, commercial sector.

The industrial sector consumes a larger amount of energy Zamarripa et al. (2018) that has a leading role in economic growth. The study has used the cointegration test and found a significant long-run linkage between electricity consumption and industrial output in the case of Mexico. The granger causality test reveals that granger causality occurs from energy consumption to GDP. Similarly, like Nawaz et. al (2021 the study of Han (2019) stated on the intensity of energy and value-added of the industrial sector in China and concluded an influential impact of energy on economic development. The intensity of energy divulged a greater upshot on economic development along with industrial output performance. Primarily, economic development was directly dependent on the intensity of energy as well as on the efficiency level of energy in this state. Higher energy intensity and lower efficiency were considered a core facet for the betterment of industrial growth and economic development. However, the manifestation of energy was considered an imperative pillar for urbanization, globalization and industrialization in most developing countries dada (2018). The intensification of energy usage provided a chief indication that energy directly caused to increase the industrial output, urbanization along human development.

Alrajhi and Al-Abdulra (2018) conducted an empirical study to discuss the consequences of energy on economic growth. They were of the view that like Rastegaripour et al. (2019) a considerable improvement in the energy sector was required to arise economic growth in Saudi Arabia because it was considered an imperative deriving force alike labor and capital for the economies. Classical growth theories were focused more on labor and capital but they neglected the role of electricity that so complements factors like labor and capital for the production process or to boost up economic growth. However, the study found a causal relationship between energy and output level of economy same like studies Sineviciene et al. (2017) in European countries and Matei (2017) organization for Economic Cooperation and Development (OECD) countries. Nasir et al. (2021) endeavoured to examine the energy consumption nexus with industrial output and agricultural output in Pakistan, 
using time series data over the period 1999-2019 for empirical analysis. They also stated the same consequences as Ramachandra et al. (2005) in which they manifested a leading role of the energy sector with the socio-economic, industrial and economic development of any state. They reported evidence that almost twenty per cent of the world population is connected and devours with the sixty per cent energy source in industrialized countries that are nearby 1 billion. While the forty per cent of energy source is connected with other five billion people in developing countries along with 2 billion low-income groups that consume energy and try to ensure an effort for sustainable growth performance.

The research gap has also seemed on the subject; as many studies have not discussed on industrial output-energy nexus at the disaggregated level in Pakistan especially by using recently 29 years data. The shortcoming also seems in the present study. As the data of 2020-21 is not taken in current research due to the unavailability of the data set because of the covid-19 period. The renewable energy source is also not included in analyzing the energy-industrial output nexus.

\section{Research Methodology}

This segment covers the data, modelling and methodology that have been used to explore the effects of energy consumption on industrial output. The annual time series data has been taken over the period 1990-2019. For empirical analysis, the ARDL technique has been employed.

\section{Data: Sources and Description}

The time-series data have been taken from the world bank and Pakistan economic survey (2019-20). Energy consumption including oil consumption (in tons), gas consumption (cubic feet), electricity consumption GigaWatt hours $(\mathrm{GWh})$ data has been generated from Pakistan economic survey (2019-20). The data of exports, imports (in constant local currency unit) related to the industrial sector and ratio of industrial income (in constant local currency unit) is the measure for trade openness $\&$ it has also been generated from Pakistan economic survey. While, the total labor force (in million) in the industrial sector, gross fixed capital formation (in constant local currency unit) in the industrial sector and industrial value-added (in constant local currency unit), data have been used from the world bank. 


\section{Model Specification}

The existing study is based on Solow Growth Model. We construct the theoretical model to examine the relationship between energy consumption and industrial output following the assumptions of the Solow Model. The Cobb-Douglas production function is given as: $Y_{t}=T_{t} K_{t}^{\beta} N_{t}^{1-\beta}$

\section{(1)}

Where $\mathrm{Y}=$ output level, $\mathrm{T}=$ the level of technology, $\mathrm{N}=$ Labor force, $\mathrm{K}=$ level of capital

Based on the assumptions of Solow growth model

$$
y_{t}=f\left(k_{t}^{\beta}\right)
$$

\section{(2)}

Where $y_{t}$ is output per worker, $k_{t}$ is capital per worker.

The fundamental Solow-Swan growth equation can be written as; $k_{t}^{\bullet}=s_{t}^{k} k_{t}^{\beta}-(n+\delta) \cdot k_{t}$

$s_{t}^{k} k_{t}^{\beta}=$ actual level of investment

$(n+\delta) \cdot k_{t}=$ breakeven level of investment

According to model When $s_{t}^{k} k_{t}^{\beta}=(n+\delta) \cdot k_{t}$

Then growth rate of capital $k_{t}^{\bullet}$ becomes zero.

So, equation 3 can be re write as;

$$
s_{t}^{k} k_{t}^{\beta}-(n+\delta) \cdot k_{t}=0
$$

$$
\begin{aligned}
& s_{t}^{k} k_{t}^{\beta}=(n+\delta) \cdot k_{t} \\
& \frac{s_{t}^{k}}{(n+\delta)}=\frac{k_{t}}{k_{t}^{\beta}}
\end{aligned}
$$

or

$$
\frac{k_{t}}{k_{t}^{\beta}}=\frac{s_{t}^{k}}{(n+\delta)}
$$




$$
\begin{aligned}
& k_{t}^{1-\beta}=\frac{s_{t}^{k}}{(n+\delta)} \\
& k_{t}=\left[\frac{s_{t}^{k}}{(n+\delta)}\right]^{\frac{1}{1-\beta}}
\end{aligned}
$$

By substituting Equation (5) in equation (2)

$$
y_{t}=\left[\left[\frac{s_{t}^{k}}{(n+\delta)}\right]^{\frac{1}{1-\beta}}\right]^{\beta}
$$

The extended form of model can be rewrite by incorporating energy as endogenous variable, as productivity factor;

$$
Y_{t}=T_{t} \times K_{t}^{\beta} \times E_{t}^{\theta}
$$

Based on Solow-Swan model assumptions, the equation (7) takes the form;

$y_{t}=k_{t}^{\beta} \times e_{t}^{\theta} \times A$

The basic equation of Solow-Swan Model can be re write as;

$$
e_{t}^{\bullet}=s_{t}^{e} e^{\theta}-(n+\delta) e_{t}
$$

Steady state condition exists where;

$\therefore e_{t}^{\bullet}=0$

Or where the actual level of investment equals to break-even level of investment.

$$
s_{t}^{e} e^{\theta}=(n+\delta) e_{t}
$$

$$
\frac{s_{t}^{e}}{(n+\delta)}=\frac{e_{t}}{e_{t}^{\theta}}
$$

or

$$
\frac{e_{t}}{e_{t}^{\theta}}=\frac{s_{t}^{e}}{(n+\delta)}
$$




$$
\begin{aligned}
& e_{t}^{1-\theta}=\frac{s_{t}^{e}}{(n+\delta)} \\
& e_{t}=\left[\frac{s_{t}^{e}}{(n+\delta)}\right]^{\frac{1}{1-\theta}}
\end{aligned}
$$

By connecting the equation (6) and equation (8), the extended Solow-Swan model can be written as;

$$
y_{t}=\left[\left[\frac{s_{t}^{k}}{(n+\delta)}\right]^{\frac{1}{1-\beta}}\right]^{\beta} \times\left[\left[\frac{s_{t}^{e}}{(n+\delta)}\right]^{\frac{1}{1-\theta}}\right]^{\theta} \times A
$$

\section{(12)}

By taking the natural log of equation (12);

$\ln y_{t}=\ln \left[\left[\frac{s_{t}^{k}}{(n+\delta)}\right]^{\frac{1}{1-\beta}}\right]^{\beta} \times \ln \left[\left[\frac{s_{t}^{e}}{(n+\delta)}\right]^{\frac{1}{1-\theta}}\right]^{\theta} \times \ln A$

$\ln y_{t}=\frac{\beta}{1-\beta} \ln s_{t}^{k}-\frac{\beta}{1-\beta} \ln (n+\delta)+\frac{\theta}{1-\theta} \ln s_{t}^{e}-\frac{\theta}{1-\theta} \ln (n+\delta)+\ln A_{t}$ $\ln y_{t}=-\left(\frac{\beta}{1-\beta}+\frac{\theta}{1-\theta}\right) \ln (n+\delta)+\frac{\beta}{1-\beta} \ln s_{t}^{k}+\frac{\theta}{1-\theta} \ln s_{t}^{e}+\psi Z_{t}$

$\therefore \psi$ shows the parameter of vectors. While $Z_{t}$ indicates the vectors of variables that determine the output level.

$\ln y_{t}=\alpha_{0}+\beta \ln s_{t}^{k}+\theta \ln s_{t}^{e} \psi Z_{t}+\varepsilon_{t}$

Where $\alpha_{0}=-\left(\frac{\beta}{1-\beta}+\frac{\theta}{1-\theta}\right) \ln (n+\delta), \quad \beta=\frac{\beta}{1-\beta}, \theta=\frac{\theta}{1-\theta}$

The econometrics description of augmented Solow-Swan Model is given in equation (13). Furthermore, three variables are used as energy consumption i.e., electricity consumption, gas consumption, oil consumption for further sorting. Similarly, the trade openness is used as control variable in the model and it is used in $\mathrm{Zt}$ in equation (10). Though, we inscribe that 
$\mathrm{Y}=f(\mathrm{~L}, \mathrm{~K}, \mathrm{Oil}, \mathrm{Elec}, \mathrm{Gas})$

Further it can rewrite by including openness as control variable with energy;

$I N D O=f(L B I N D, C P I N D$, OILIND, ELECIND, GASIND, OPENESS $)$

\section{(15)}

Where INDO= Industrial value-added (in million rupees)

LBIND $=$ Labor employed in industry (in million)

$\mathrm{CPIND}=$ Capital in the industry (in million rupees)

OILIND $=$ Oil consumption in the industry (in tons)

ELECIND $=$ Electricity consumption in industry (in gaga watt hours)

GASIND $=$ Gas consumption in industry (in cubic feet)

OPENESS = Trade openness of industry (in million rupees)

In econometrics form;

$I N D O_{t}=\beta_{o}+\beta_{1}$ LBIND $_{t}+\beta_{2}$ CPIND $_{t}+\beta_{3}$ OILIND $_{t}+\beta_{4}$ GASIND $_{t}+\beta_{5}$ ELECIND $_{t}+\beta_{6}$ OPENESS $_{t}+\mu_{t}$

(16)

$$
\beta_{1}, \beta_{2}, \beta_{3}, \beta_{4}, \beta_{5}, \beta_{6} \mathrm{f} 0
$$

The regression of model related to the present study can be rewritten in Autoregressive Distributed Lag (ARDL) equation form as; $\Delta(I N D O)_{t}=\beta_{o}+\beta_{1}(I N D O)_{t-1}+\beta_{2}(\text { LBIND })_{t-1}+\beta_{3}(\text { CPIND })_{t-1}+\beta_{4}(\text { OILIND })_{t-1}+\beta_{5}(\text { GASIND })_{t-1}+$

$$
\begin{gathered}
\beta_{6}(\text { ELECIND })_{t-1}+\beta_{7}(\text { OPENESS })_{t-1}+\sum_{i=1}^{\Re} \mathrm{D}_{1} \Delta(\text { INDO })_{t-i}+\sum_{i=0}^{\Re} \mathrm{D}_{2} \Delta(\text { LBIND })_{t-i}+ \\
\sum_{i=0}^{\Re} \mathrm{D}_{3} \Delta(\text { CPIND })_{t-i}+\sum_{i=0}^{\Re} \mathrm{D}_{4} \Delta(\text { OILIND })_{t-i}+\sum_{i=0}^{\Re} \mathrm{D}_{5} \Delta(\text { GASIND })_{t-i}+ \\
\sum_{i=0}^{\Re} \mathrm{D}_{6} \Delta(\text { ELECIND })_{t-i}+\sum_{i=0}^{\Re} \mathrm{D}_{7} \Delta(\text { OPENESS })_{t-i}+\mu_{t}
\end{gathered}
$$

$$
\begin{aligned}
I N D O_{t}= & \beta_{0}+\sum_{i=1}^{\Re} \mathrm{D}_{i i}(\text { INDO })_{t-i}+\sum_{i=0}^{\Re} \mathrm{D}_{2 i}(\text { LIIND })_{t-i}+\sum_{i=0}^{\mathscr{M}} \mathrm{D}_{3 i}(\text { CPIND })_{t-i}+\sum_{i=0}^{\mathscr{\Re}} \mathrm{D}_{4 i}(\text { OILIND })_{t-i} \\
& +\sum_{i=0}^{\Re} \mathrm{D}_{5 i}(\text { GASIND })_{t-i}+\sum_{i=0}^{\Re} \mathrm{D}_{6 i}(\text { ELECIND })_{t-i}+\sum_{i=0}^{\Re} \mathrm{D}_{7 i}(\text { OPENESS })_{t-i}+\mu_{t}
\end{aligned}
$$


(18)

Equation 6 shows the long run parameters of industrial output model.

$\Delta(I N D O)_{t}=\mathrm{D}_{o}+\sum_{i=1}^{\Re} \mathrm{D}_{i i} \Delta(I N D O)_{t-i}+\sum_{i=0}^{\Re h} \mathrm{D}_{2 i} \Delta(\text { LBIND })_{t-i}+\sum_{i=0}^{\Re h} \mathrm{D}_{3 i} \Delta(C P I N D)_{t-i}+\sum_{i=0}^{\Re h} \mathrm{D}_{4 i} \Delta(\text { OILIND })_{t-i}$

$+\sum_{i=0}^{\Re} \mathrm{D}_{5 i} \Delta(\text { GASIND })_{t-i}+\sum_{i=0}^{\Re} \mathrm{D}_{6 i} \Delta(\text { ELECIND })_{t-i}+\sum_{i=0}^{\Re} \mathrm{D}_{7 i} \Delta(\text { OPENESS })_{t-i}+\lambda(\text { ECM })_{T-1}+\mu_{t}$

(19) The short run parameters of industrial output model are given in equation 7.

$$
\Delta \mathrm{P}_{t}=\partial+\Upsilon \Delta \mathrm{X}_{t-1}+\mathrm{D}\left(E C M_{t-1}\right)+\mu_{0}
$$

$E C M_{t-1}$ is the lagged error term of the model and D is the coefficient value of ECM, that shows the speed of adjustment.

\section{Results and Discussions}

\section{Descriptive Statistics and Correlation Analysis}

To measure the central tendency and variability, the descriptive statistics analysis is done in Table 1. The average value of Industrial Output (INDO), Capital in Industry (CPIND), Labor in Industry (LBIND), Oil consumption in Industry (OILIND), Trade Openness (OPENESS), Electricity consumption in Industry (ELECIND), Gas in Industry (GASIND) is 14.15, 0.29, 2.432, 14.26, -0.34 and 9.77 respectively. The variability in Capital in Industry (CPIND) and Trade Openness (OPENESS) values is seemed high as compared to the values of Industrial Output (INDO), Labor in Industry (LBIND), Oil consumption in Industry (OILIND), and Electricity consumption in Industry (ELECIND). Likewise, the values of skewness and kurtosis show that all variables are negatively skewed or have the platykurtic condition.

Table 1: Descriptive Statistics and Correlation Matrix

\begin{tabular}{|c|c|c|c|c|c|c|c|}
\hline & $\begin{array}{l}\text { IND } \\
\text { O }\end{array}$ & $\begin{array}{l}\text { LBI } \\
\text { ND }\end{array}$ & $\begin{array}{l}\text { CPI } \\
\mathbf{N}\end{array}$ & $\begin{array}{l}\text { ELE } \\
\text { CIN }\end{array}$ & $\begin{array}{l}\text { GAS } \\
\text { IN }\end{array}$ & $\begin{array}{l}\text { OIL } \\
\text { IN }\end{array}$ & $\begin{array}{l}\text { OPEN } \\
\text { ESS }\end{array}$ \\
\hline Mean & $\begin{array}{l}14.1 \\
59\end{array}$ & $\begin{array}{l}2.43 \\
2\end{array}$ & 0.290 & 9.777 & $\begin{array}{l}12.1 \\
46\end{array}$ & $\begin{array}{l}14.2 \\
68\end{array}$ & -0.343 \\
\hline
\end{tabular}


PerennialJournal of History, Vol II. No.II

\begin{tabular}{|c|c|c|c|c|c|c|c|}
\hline $\begin{array}{l}\text { Media } \\
\text { n }\end{array}$ & $\begin{array}{l}14.2 \\
28\end{array}$ & $\begin{array}{l}2.40 \\
9\end{array}$ & 0.560 & 9.850 & $\begin{array}{l}12.3 \\
35\end{array}$ & $\begin{array}{l}14.2 \\
86\end{array}$ & -0.190 \\
\hline $\begin{array}{l}\text { Maxim } \\
\text { um }\end{array}$ & $\begin{array}{l}14.7 \\
48\end{array}$ & $\begin{array}{l}3.06 \\
4\end{array}$ & 1.640 & $\begin{array}{l}10.26 \\
7\end{array}$ & $\begin{array}{l}12.7 \\
17\end{array}$ & $\begin{array}{l}14.6 \\
98\end{array}$ & 0.589 \\
\hline $\begin{array}{l}\text { Minim } \\
\text { um }\end{array}$ & $\begin{array}{l}13.4 \\
91\end{array}$ & $\begin{array}{l}1.98 \\
0\end{array}$ & $-\overline{1.501}$ & 9.326 & $\begin{array}{l}11.3 \\
95\end{array}$ & $\begin{array}{l}13.7 \\
84\end{array}$ & -1.678 \\
\hline $\begin{array}{l}\text { Std. } \\
\text { Dev. }\end{array}$ & $\begin{array}{l}0.39 \\
8 \\
\end{array}$ & $\begin{array}{l}0.34 \\
3 \\
\end{array}$ & 0.917 & 0.303 & $\begin{array}{l}0.45 \\
6 \\
\end{array}$ & $\begin{array}{l}0.23 \\
9 \\
\end{array}$ & 0.667 \\
\hline $\begin{array}{l}\text { Skewn } \\
\text { ess }\end{array}$ & $\begin{array}{l}- \\
0.10 \\
3 \\
\end{array}$ & $\begin{array}{l}0.25 \\
5\end{array}$ & $\begin{array}{l}- \\
0.263\end{array}$ & -0.027 & $\begin{array}{l}- \\
0.29 \\
8 \\
\end{array}$ & $\begin{array}{l}- \\
0.26 \\
2 \\
\end{array}$ & -0.309 \\
\hline $\begin{array}{l}\text { Kurtos } \\
\text { is }\end{array}$ & $\begin{array}{l}1.61 \\
4\end{array}$ & $\begin{array}{l}1.80 \\
1\end{array}$ & 1.992 & 1.554 & $\begin{array}{l}1.46 \\
5\end{array}$ & $\begin{array}{l}2.38 \\
1\end{array}$ & 1.808 \\
\hline INDO & 1 & & & & & & \\
\hline LBIN & $\begin{array}{l}0.97 \\
7\end{array}$ & 1 & & & & & \\
\hline $\begin{array}{l}\text { CPIN } \\
\text { D }\end{array}$ & $\begin{array}{l}0.98 \\
8 \\
\end{array}$ & $\begin{array}{l}0.95 \\
8 \\
\end{array}$ & 1 & & & & \\
\hline $\begin{array}{l}\text { ELEC } \\
\text { IN }\end{array}$ & $\begin{array}{l}0.97 \\
6 \\
\end{array}$ & $\begin{array}{l}0.97 \\
4 \\
\end{array}$ & 0.964 & 1 & & & \\
\hline $\begin{array}{l}\text { GASI } \\
\mathbf{N} \\
\end{array}$ & $\begin{array}{l}0.91 \\
8 \\
\end{array}$ & $\begin{array}{l}0.85 \\
5 \\
\end{array}$ & 0.901 & 0.901 & 1 & & \\
\hline OILIN & $\begin{array}{l}- \\
0.28 \\
3\end{array}$ & $\begin{array}{l}- \\
0.28 \\
3\end{array}$ & 0.210 & -0.336 & $\begin{array}{l}- \\
0.46 \\
8\end{array}$ & 1 & \\
\hline $\begin{array}{l}\text { OPEN } \\
\text { ESS } \\
\end{array}$ & $\begin{array}{l}0.98 \\
9 \\
\end{array}$ & $\begin{array}{l}0.96 \\
2 \\
\end{array}$ & 0.983 & 0.969 & $\begin{array}{l}0.92 \\
2 \\
\end{array}$ & $\begin{array}{l}0.25 \\
8 \\
\end{array}$ & 1 \\
\hline
\end{tabular}

Source: Authors' calculations

The correlation matrix of the model is also done to examine the correlation among the variables i.e., Industrial Output (INDO), Labor in Industry (LBIND), Capital in Industry (CPIND), Oil in Industry (OILIND), Trade Openness (OPENESS), Electricity in 
Industry (ELECIND), Gas in Industry (GASIND). The strong and positive connection of industrial Output (INDO) is reported with Capital in Industry (CPIND), Electricity Consumption in Industry (ELECIND), Gas Consumption in Industry (GASIND), Labor in Industry (LBIND), and Trade Openness (OPENESS) except Oil Consumption in Industry (OILIND) that has lesser linkage with industrial output. Though, oil consumption is just a variable that is not strongly connected with all the variables except all other variables that have strong connection with each other in Table 1.

\section{Unit Root Analysis}

Table 2 shows the results of the Augmented Dickey-Fuller Test that has been used to point out the unit root of used variables. The Augmented Dickey-Fuller (ADF) results reveal that some variables are integrated at I(0) and some other variables with $\mathrm{I}(\mathrm{I})$.

\section{Table 2: Unit Root Test (Augmented Dickey-Fuller test)}

\begin{tabular}{|c|c|c|c|c|c|c|c|}
\hline \multirow{2}{*}{$\begin{array}{l}\text { Varia } \\
\text { bles }\end{array}$} & \multicolumn{2}{|l|}{ level } & & \multicolumn{2}{|c|}{$1^{\text {st }}$ difference } & \multirow[b]{2}{*}{$\begin{array}{l}\text { Non } \\
\text { e }\end{array}$} & \multirow[b]{2}{*}{$\begin{array}{l}\text { Concl } \\
\text { usion }\end{array}$} \\
\hline & $\begin{array}{l}\text { Inter } \\
\text { cept }\end{array}$ & $\begin{array}{l}\text { Tren } \\
\text { d \& } \\
\text { Inter } \\
\text { cept }\end{array}$ & $\begin{array}{l}\text { Non } \\
\text { e }\end{array}$ & $\begin{array}{l}\text { Inter } \\
\text { cept }\end{array}$ & $\begin{array}{l}\text { Tren } \\
\text { d \& } \\
\text { Inter } \\
\text { cept }\end{array}$ & & \\
\hline INDO & $\begin{array}{l}- \\
1.106\end{array}$ & $-\overline{1.569}$ & $\begin{array}{l}6.14 \\
6\end{array}$ & $\begin{array}{l}- \\
4.569 \\
*\end{array}$ & $\begin{array}{l} \\
4.593 \\
*\end{array}$ & $\begin{array}{l}- \\
2.60 \\
8^{*}\end{array}$ & $\mathrm{I}(1)$ \\
\hline $\begin{array}{l}\text { LBIN } \\
\text { D }\end{array}$ & 1.074 & $\begin{array}{l}3.263 \\
* * *\end{array}$ & $\begin{array}{l}4.23 \\
7\end{array}$ & $\begin{array}{l}- \\
5.666 \\
*\end{array}$ & $\begin{array}{l}- \\
5.946 \\
*\end{array}$ & $\begin{array}{l}- \\
3.63 \\
9 *\end{array}$ & $\mathrm{I}(0)$ \\
\hline $\begin{array}{l}\text { CPIN } \\
\text { D }\end{array}$ & $-\overline{1.674}$ & $-\overline{2.689}$ & $\begin{array}{l}- \\
0.38 \\
1 \\
\end{array}$ & $\begin{array}{l}- \\
4.606 \\
*\end{array}$ & $-\overline{4.733}$ & $\begin{array}{l}- \\
3.10 \\
1 * \\
\end{array}$ & $\mathrm{I}(1)$ \\
\hline $\begin{array}{l}\text { OILI } \\
\text { ND }\end{array}$ & $-\overline{2.273}$ & $-\overline{2.500}$ & $\begin{array}{l}0.37 \\
7\end{array}$ & $\begin{array}{l}- \\
4.485 \\
*\end{array}$ & $\begin{array}{l}- \\
4.329 \\
*\end{array}$ & $\begin{array}{l}- \\
4.56 \\
2 *\end{array}$ & $\mathrm{I}(1)$ \\
\hline $\begin{array}{l}\text { ELEC } \\
\text { IND }\end{array}$ & $\begin{array}{l}- \\
0.644\end{array}$ & $\begin{array}{l}- \\
1.877\end{array}$ & $\begin{array}{l}- \\
3.66 \\
7 * *\end{array}$ & $\begin{array}{l}- \\
3.947 \\
*\end{array}$ & $\begin{array}{l}- \\
3.862 \\
* *\end{array}$ & $\begin{array}{l}- \\
3.44 \\
6\end{array}$ & $\mathrm{I}(0)$ \\
\hline $\begin{array}{l}\text { GASI } \\
\text { ND }\end{array}$ & $\begin{array}{l}- \\
1.784\end{array}$ & 0.095 & $\begin{array}{l}0.58 \\
9 \\
\end{array}$ & $\begin{array}{l} \\
2.494\end{array}$ & $\begin{array}{l} \\
2.889\end{array}$ & $\begin{array}{l}2.53 \\
6^{* *}\end{array}$ & $\mathrm{I}(1)$ \\
\hline
\end{tabular}




\begin{tabular}{|l|l|l|l|l|l|l|l|}
\hline $\begin{array}{l}\text { OPEN } \\
\text { ESS }\end{array}$ & 1.461 & - & 5.71 & - & - & - & $\mathrm{I}(1)$ \\
& & 1.642 & 6 & $\begin{array}{l}4.352 \\
*\end{array}$ & $\begin{array}{l}4.881 \\
*\end{array}$ & $\begin{array}{l}2.50 \\
2 * *\end{array}$ & \\
\hline
\end{tabular}

Note: Authors' calculations

It justifies using ARDL approach for empirical analysis so we have employed the ARDL approach to finding the long run and short-run relationship of the existing model.

\section{Bounds Test Analysis}

Before ARDL approach, firstly, the bounds test has been used to examine the long-run association among the variables in Table 3.

\section{Table 3: Bounds Test}

F-Bounds Test

Test Statistic
Null Hypothesis: No levels

\section{Relationship}

Value Sign $\quad \mathbf{I}(0)$

I(1)

\begin{tabular}{lllll} 
& & \multicolumn{3}{c}{$\begin{array}{l}\text { Asymptotic: } \\
\mathrm{n}=1000\end{array}$} \\
F-statistic & 21.893 & $10 \%$ & 2.12 & 3.23 \\
K & 6 & $5 \%$ & 2.45 & 3.61 \\
& & $2.5 \%$ & 2.75 & 3.99 \\
& & $1 \%$ & 3.15 & 4.43
\end{tabular}

Source: Authors' Calculations

The rejection of the null hypothesis seems clearly in the above table which states that there is no existence of a long-run relationship among the used variables. The F-statistics value shows that industrial output is strongly connected with the energy consumption along with labor, capital and trade openness of the industry sector in the long run. It is because the F-statistics value lies above the upper limit I (1) that provides strong evidence of long-run cointegration among the variables.

Long Run and Error Correction Analysis 
Table 5 elucidates the long run results of the model, where industrial value-added is taken as a dependent variable while Capital in Industry (CPIND), Labor in Industry (LBIND), Oil in Industry (OILIND), Trade Openness related to Industry (OPENESS), Electricity in Industry (ELECIND), Gas in Industry (GASIND) are presumed as independent variables.

The labor force is considered a core fragment for the progress of industrial output. The up-gradation in the industry sector is not possible without the effective role of labor force in today's world. Similarly, the structural changes in the economy are based on the extent of labor force and capital Rastegaripour et al. (2019). The Working labor force in the industry sector has a positive and significant effect on industry output in the long run. Results predict that any increase in LBIND would increase the industry output progressively. It is assumed that working labor force contribution in the industry sector is increasing, it may be because of rising in efficiency level, skills and education. The classical theory also supports the same verdict in which they use labor as a core variable with the given capital for the production process Meade (1961). Our results are the same as the studies Manyika et al. (2017) and Moeuf et al. (2018) found the same results of working labor force in the industry sector.

\section{Table 5: Long Run Results}

\begin{tabular}{|c|c|c|c|c|}
\hline \multicolumn{5}{|c|}{$\begin{array}{l}\text { Dependent Variable: INDO } \\
\text { ARDL }(2,2,2,1,2,1,2)\end{array}$} \\
\hline Variable & Coefficient & $\begin{array}{l}\text { Std. } \\
\text { Error }\end{array}$ & t-Statistic & Prob. \\
\hline LBIND & 0.164 & 0.044 & 3.712 & 0.034 \\
\hline CPIND & 0.123 & 0.020 & 6.071 & 0.009 \\
\hline OILIND & 0.103 & 0.013 & 7.850 & 0.004 \\
\hline ELECIND & 0.977 & 0.107 & 9.051 & 0.000 \\
\hline GASIND & 0.260 & 0.076 & 3.410 & 0.002 \\
\hline OPENESS & 0.356 & 0.058 & 6.180 & 0.009 \\
\hline $\mathbf{C}$ & 16.859 & 2.725 & 6.187 & 0.009 \\
\hline
\end{tabular}

Capital is considered an engine for the evolution in the industry sector. According to neoclassical theory, labor and capital are leading factors that stimulate the production process. The expansion 
in the industry is rely more on the substantial levels of quantity and quality of capital MTSNO (2015). The value of capital in industry is 0.12 which means that one unit increase in CPIND further increases the industrial output by 0.12 million. CPIND has a strong and significant impact on industrial output. It is assumed that it may be due to improvement in infrastructure that can stimulate productive capacities in industrial output. Other channels may be that because of increase in investment level by spending in various projects can increase the industrial output level progressively. Current results stay in the line with Mohsen (2015) in which he found a strong and significant effect of capital on industrial output. Energy consumption is a domineering factor for the evolution of technological framework and is considered a vital pillar for the progress of industry output. The wheel of life is directly connected with the energy instruments so that the world is striving today to achieve a progressive industrial output as well as economic growth performance through this influential factor Nasir et al. (2021). The core variables, oil, gas and electricity consumption are taken as energy variables in the current model. Oli consumption is positively and significantly related to the industry output. It is assumed that a one-unit increase in oil would raise the industry output by 0.10 million. Oil is considered a major instrument in today's world for the survival of the economic wheel. Though, it is expected that it may be due to the rise in technology and new mechanization in the output process that now a day's economic life is unable to run without the use of oil consumption. Our results are the same in the line of Zhu et al. (2016) for China and Hamdi et al. (2019) for oilexporting countries, in which they found a strong association of oil consumption with industrial output.

Electricity consumption is positively and significantly connected with the industrial sector output. It predicts that because of some effective means of the utilization of plants, the electricity role in different areas promotes the output level in the industry. It is considered a mainstay for the industrialization process because of using advanced mechanisms Zamarripa et al. (2018). However, our results are matchable with the study Han (2019) while contrary with the studies Nigeria study Ibrahim et al. (2017) and Ghana study of Abokyi et al. (2018). Likewise, similar verdicts have been detected for gas consumption and industrial output. It may be due to the 
abundance of natural resources domestically and supply chain that could enhance the production capacity in the industry sector. The results are the same as the studies Li et al. (2019) for China and Nasir et al. (2021) for Pakistan, in which they discovered the same outcomes between gas consumption and industrial sector output. It shows that a one-unit increase in gas consumption would increase the industrial output by 0.26 million.

Trade openness is a control variable that has an influential effect on industrial output. It has a greater extent in exports related to the industrial sector which improves the balance of payments (BOP) so that further it stimulates output level of industry progressively Chien et al. (2021). The coefficient value of trade openness (OPENESS) shows that there is a positive and significant linkage of trade openness (OPENESS) with industrial output. It is assumed that anyone unit increase in trade openness would increase the industrial output by 0.36 million. The reason is that it may be because of rising the output capacity from imports through the inputs tools and production capacity from exports related to the industry sector. The estimated results are the same alike Zhuang et al. (2021) study in which they found the same results.

Table 6: Error Correction Analysis

\begin{tabular}{|l|l|l|l|l|}
\hline Dependent Variable: INDO \\
\hline Variable & Coefficient & $\begin{array}{l}\text { Std. } \\
\text { Error }\end{array}$ & $\begin{array}{l}\text { t- } \\
\text { Statistic }\end{array}$ & Prob. \\
\hline C & 16.859 & 0.786 & 21.448 & 0.000 \\
\hline D(INDO(-1)) & -0.622 & 0.045 & -13.899 & 0.001 \\
\hline D(INDO(-2)) & -0.068 & 0.032 & -2.173 & 0.118 \\
\hline D(LBIND) & -0.368 & 0.030 & -12.315 & 0.001 \\
\hline D(LBIND(-1)) & -0.683 & 0.045 & -15.210 & 0.001 \\
\hline D(LCPIN) & 0.022 & 0.012 & 1.916 & 0.151 \\
\hline D(LCPIN(-1)) & 0.037 & 0.012 & 3.031 & 0.056 \\
\hline D(ELECIN) & -0.152 & 0.027 & -5.724 & 0.011 \\
\hline D(ELECIN(-1)) & -0.634 & 0.043 & -14.899 & 0.001 \\
\hline D(GASIN) & 0.271 & 0.013 & 20.244 & 0.000 \\
\hline D(OILIN) & 0.022 & 0.007 & 3.072 & 0.055 \\
\hline D(LOPENESS) & 0.472 & 0.029 & 16.083 & 0.001 \\
\hline $\begin{array}{l}\text { D(LOPENESS(- } \\
\text { 1)) }\end{array}$ & -0.044 & 0.019 & -2.304 & 0.105 \\
\hline
\end{tabular}




\begin{tabular}{|l|l|l|l|l|}
\hline $\mathbf{E C M}(-1)^{*}$ & -1.533 & 0.071 & -21.442 & 0.000 \\
\hline
\end{tabular}

Table 6 indicates the short-run results on energy consumption and industrial output model. ECM value is -1.533 with standard deviation 0.071 , $\mathrm{t}$ - statistics value -21.42 , and P-value 0.000 which indicates that the speed of adjustment from short run to long run will occur at 1.53 per cent each year. The significant condition also further verdicts the existence of a long-run relationship among the variables in future.

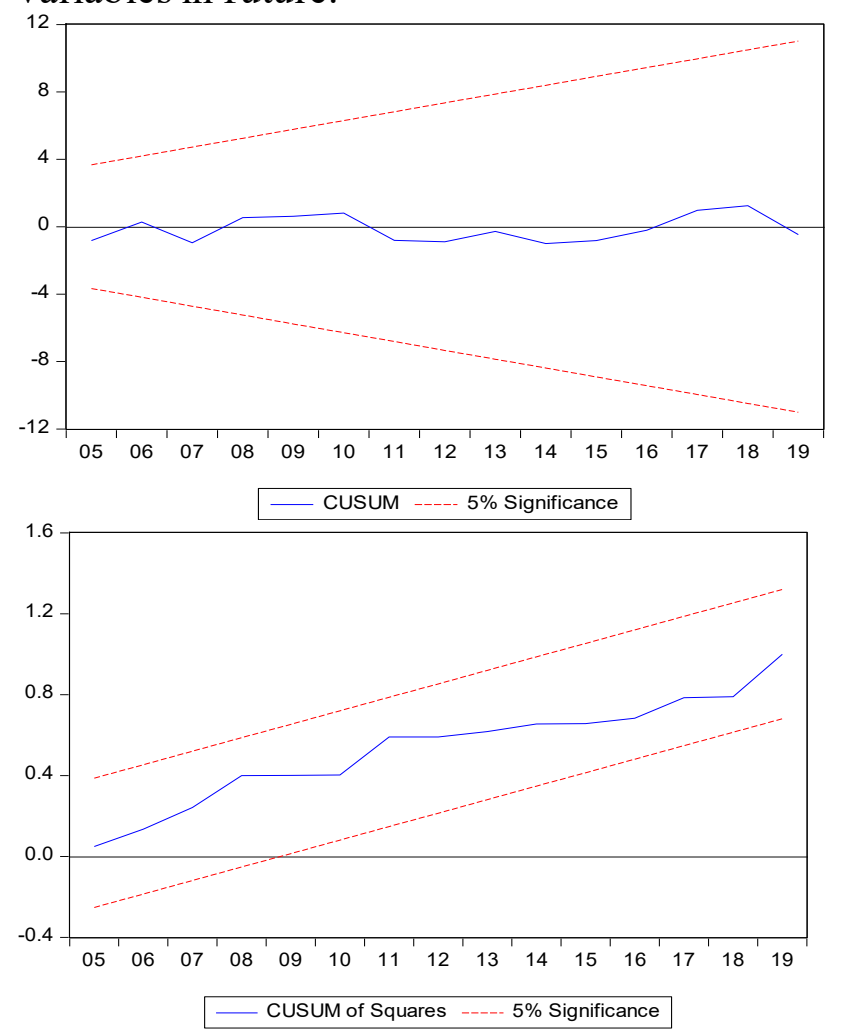

The present study also draws the Cumulative Sum of Recursive Residuals (CUSUM) and Cumulative Sum of Recursive Residuals (CUSUM) of square graphs to check the stability condition of the model. Though, the stable condition between the long and short-run estimates seems clearly in both Cumulative Sum of Recursive Residuals (CUSUM) and Cumulative Sum of Recursive Residuals (CUSUM) of square graphs. However, there is no evidence of 
divergence is observed in both CUSUM and CUSUM of square graphs.

\section{Causality Analysis}

It has been attempted to check the causality analysis between the variables related to energy consumption and industrial output in Section 6.

Table 7 shows that there exists a unidirectional causality from electricity consumption to industrial output (Abokyi et al. 2018) due to the rejection of the null hypothesis of ELECIN does not Granger Cause INDO at the optimal lag length criteria that is assumed 1 due to having more significance condition of outcomes. The same results of causality are predicted at lag 2 while except other lag length criteria.

\section{Table 7: Granger Causality Analysis}

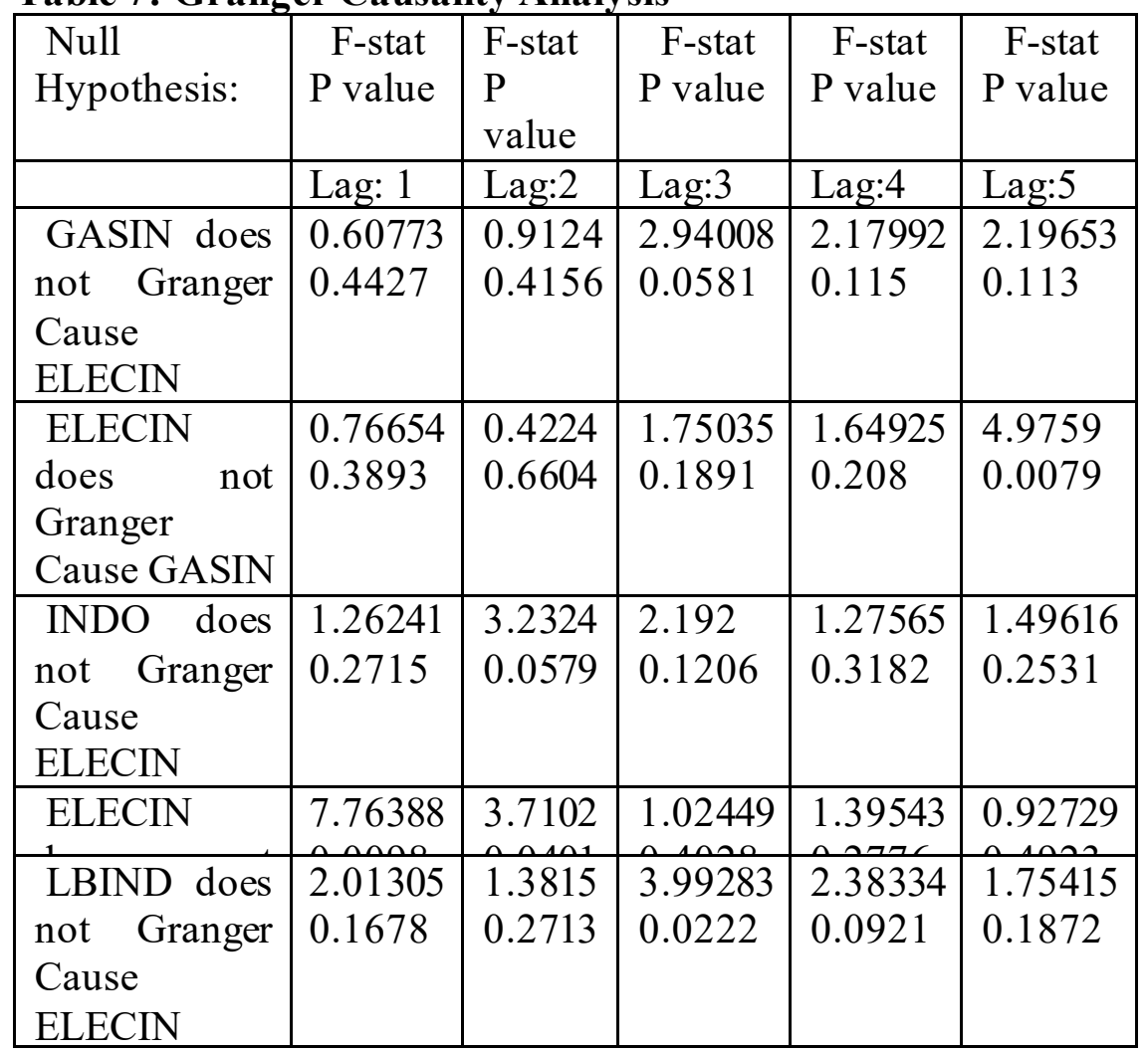


Perennial Journal of History, Vol II. No. II

\begin{tabular}{|c|c|c|c|c|c|}
\hline $\begin{array}{l}\text { ELECIN } \\
\text { does not } \\
\text { Granger } \\
\text { Cause LBIND }\end{array}$ & $\begin{array}{l}2.80353 \\
0.1060\end{array}$ & $\begin{array}{l}0.8594 \\
0.4367\end{array}$ & $\begin{array}{l}1.36165 \\
0.2831\end{array}$ & $\begin{array}{l}0.94625 \\
0.4614\end{array}$ & $\begin{array}{l}1.07406 \\
0.4157\end{array}$ \\
\hline $\begin{array}{l}\text { OILIN does } \\
\text { not Granger } \\
\text { Cause } \\
\text { ELECIN }\end{array}$ & $\begin{array}{l}0.01492 \\
0.9037\end{array}$ & $\begin{array}{l}0.1208 \\
0.8868\end{array}$ & $\begin{array}{l}0.13117 \\
0.9404\end{array}$ & $\begin{array}{l}0.29142 \\
0.8795\end{array}$ & $\begin{array}{l}0.46547 \\
0.7956\end{array}$ \\
\hline $\begin{array}{l}\text { ELECIN } \\
\text { does not } \\
\text { Granger } \\
\text { Cause OILIN }\end{array}$ & $\begin{array}{l}1.78475 \\
0.1931\end{array}$ & $\begin{array}{l}1.1829 \\
0.3243\end{array}$ & $\begin{array}{l}0.61553 \\
0.6129\end{array}$ & $\begin{array}{l}0.72374 \\
0.5877\end{array}$ & $\begin{array}{l}0.75963 \\
0.5934\end{array}$ \\
\hline \begin{tabular}{l}
\multicolumn{2}{l}{ OPENESS } \\
does not \\
Granger \\
Cause \\
ELECIN
\end{tabular} & $\begin{array}{l}2.60379 \\
0.1187\end{array}$ & $\begin{array}{l}5.1582 \\
0.0141\end{array}$ & $\begin{array}{l}2.64735 \\
0.0769\end{array}$ & $\begin{array}{l}2.40243 \\
0.0903\end{array}$ & $\begin{array}{l}2.41603 \\
0.0887\end{array}$ \\
\hline $\begin{array}{l}\text { ELECIN } \\
\text { does not } \\
\text { Granger } \\
\text { Cause } \\
\text { OPENESS } \\
\end{array}$ & $\begin{array}{l}0.86048 \\
0.3621\end{array}$ & $\begin{array}{l}0.3900 \\
0.6814\end{array}$ & $\begin{array}{l}1.15708 \\
0.3507\end{array}$ & $\begin{array}{l}1.81991 \\
0.1715\end{array}$ & $\begin{array}{l}1.15769 \\
0.377\end{array}$ \\
\hline $\begin{array}{l}\text { INDO does } \\
\text { not Granger } \\
\text { Cause } \\
\text { GASIN }\end{array}$ & $\begin{array}{l}1.30592 \\
0.2635\end{array}$ & $\begin{array}{l}2.4632 \\
0.1073\end{array}$ & $\begin{array}{l}0.8654 \\
0.4753\end{array}$ & $\begin{array}{l}4.08128 \\
0.0169\end{array}$ & $\begin{array}{l}4.66924 \\
0.0102\end{array}$ \\
\hline $\begin{array}{l}\text { GASIN does } \\
\text { not Granger } \\
\text { Cause INDO }\end{array}$ & $\begin{array}{l}0.89705 \\
0.3523\end{array}$ & $\begin{array}{l}0.9361 \\
0.4067\end{array}$ & $\begin{array}{l}0.21661 \\
0.8837\end{array}$ & $\begin{array}{l}1.50323 \\
0.2455\end{array}$ & $\begin{array}{l}1.1563 \\
0.3777\end{array}$ \\
\hline $\begin{array}{l}\text { LBIND does } \\
\text { not Granger } \\
\text { Cause } \\
\text { GASIN }\end{array}$ & $\begin{array}{l}1.55235 \\
0.2239\end{array}$ & $\begin{array}{l}0.6536 \\
0.5296\end{array}$ & $\begin{array}{l}0.52534 \\
0.6699\end{array}$ & $\begin{array}{l}1.05965 \\
0.4065\end{array}$ & $\begin{array}{l}1.91258 \\
0.1559\end{array}$ \\
\hline $\begin{array}{l}\text { GASIN does } \\
\text { not Granger } \\
\text { Cause LBIND }\end{array}$ & $\begin{array}{l}0.35162 \\
0.5583\end{array}$ & $\begin{array}{l}0.3955 \\
0.6778\end{array}$ & $\begin{array}{l}0.46177 \\
0.7121\end{array}$ & $\begin{array}{l}0.48378 \\
0.7474\end{array}$ & $\begin{array}{l}1.6413 \\
0.2135\end{array}$ \\
\hline
\end{tabular}


MuhammadUmair, Muhammad Ramzan Sheikh \& KashifSaeed

\begin{tabular}{|c|c|c|c|c|c|}
\hline $\begin{array}{l}\text { OILIN does } \\
\text { not Granger } \\
\text { Cause GASIN }\end{array}$ & $\begin{array}{l}1.95419 \\
0.1739\end{array}$ & $\begin{array}{l}1.6149 \\
0.2207\end{array}$ & $\begin{array}{l}0.17754 \\
0.9104\end{array}$ & $\begin{array}{l}0.94757 \\
0.4608\end{array}$ & $\begin{array}{l}0.91594 \\
0.4987\end{array}$ \\
\hline $\begin{array}{l}\text { GASIN does } \\
\text { not Granger } \\
\text { Cause OILIN }\end{array}$ & $\begin{array}{l}5.08697 \\
0.0327\end{array}$ & $\begin{array}{l}2.3973 \\
0.1133\end{array}$ & $\begin{array}{l}0.92543 \\
0.4466\end{array}$ & $\begin{array}{l}0.74169 \\
0.5766\end{array}$ & $\begin{array}{l}0.31957 \\
0.893\end{array}$ \\
\hline \begin{tabular}{l}
\multicolumn{2}{c}{ OPENESS } \\
does not \\
Granger \\
Cause \\
GASIN
\end{tabular} & $\begin{array}{l}0.44337 \\
0.5114\end{array}$ & $\begin{array}{l}0.0384 \\
0.9624\end{array}$ & $\begin{array}{l}2.68827 \\
0.0739\end{array}$ & $\begin{array}{l}2.94729 \\
0.0509\end{array}$ & $\begin{array}{l}3.7664 \\
0.0227\end{array}$ \\
\hline $\begin{array}{l}\text { GASIN does } \\
\text { not Granger } \\
\text { Cause } \\
\text { OPENESS }\end{array}$ & $\begin{array}{l}1.51807 \\
0.2289\end{array}$ & $\begin{array}{l}1.4331 \\
0.2591\end{array}$ & $\begin{array}{l}0.12152 \\
0.9463\end{array}$ & $\begin{array}{l}0.98793 \\
0.4405\end{array}$ & $\begin{array}{l}1.36689 \\
0.2947\end{array}$ \\
\hline $\begin{array}{l}\text { LBIND does } \\
\text { not Granger } \\
\text { Cause INDO }\end{array}$ & $\begin{array}{l}2.79627 \\
0.1065\end{array}$ & $\begin{array}{l}2.0489 \\
0.1517\end{array}$ & $\begin{array}{l}1.26885 \\
0.312\end{array}$ & $\begin{array}{l}1.55937 \\
0.2303\end{array}$ & $\begin{array}{l}1.05217 \\
0.4265\end{array}$ \\
\hline $\begin{array}{l}\text { INDO does } \\
\text { not Granger } \\
\text { Cause LBIND }\end{array}$ & $\begin{array}{l}5.99112 \\
0.0214\end{array}$ & $\begin{array}{l}1.8339 \\
0.1824\end{array}$ & $\begin{array}{l}0.46886 \\
0.7073\end{array}$ & $\begin{array}{l}0.89056 \\
0.4908\end{array}$ & $\begin{array}{l}1.21815 \\
0.3512\end{array}$ \\
\hline $\begin{array}{l}\text { OILIN does } \\
\text { not Granger } \\
\text { Cause INDO }\end{array}$ & $\begin{array}{l}0.10152 \\
0.7526\end{array}$ & $\begin{array}{l}0.1527 \\
0.8593\end{array}$ & $\begin{array}{l}1.80103 \\
0.1795\end{array}$ & $\begin{array}{l}0.7579 \\
0.5667\end{array}$ & $\begin{array}{l}1.4932 \\
0.254\end{array}$ \\
\hline $\begin{array}{l}\text { INDO does } \\
\text { not Granger } \\
\text { Cause OILIN }\end{array}$ & $\begin{array}{l}1.76047 \\
0.1961\end{array}$ & $\begin{array}{l}0.6561 \\
0.5283\end{array}$ & $\begin{array}{l}6.94462 \\
0.0022\end{array}$ & $\begin{array}{l}4.49107 \\
0.0117\end{array}$ & $\begin{array}{l}2.34131 \\
0.0963\end{array}$ \\
\hline \begin{tabular}{l}
\multicolumn{2}{l}{ OPENESS } \\
does not \\
Granger \\
Cause INDO
\end{tabular} & $\begin{array}{l}6.26152 \\
0.0190\end{array}$ & $\begin{array}{l}4.5817 \\
0.0211\end{array}$ & $\begin{array}{l}0.22312 \\
0.8792\end{array}$ & $\begin{array}{l}0.08727 \\
0.9852\end{array}$ & $\begin{array}{l}0.13917 \\
0.9802\end{array}$ \\
\hline $\begin{array}{l}\text { INDO does } \\
\text { not Granger } \\
\text { Cause } \\
\text { OPENESS }\end{array}$ & $\begin{array}{l}7.23214 \\
0.0123\end{array}$ & $\begin{array}{l}1.5597 \\
0.2316\end{array}$ & $\begin{array}{l}1.8791 \\
0.1657\end{array}$ & $\begin{array}{l}2.06093 \\
0.1311\end{array}$ & $\begin{array}{l}2.47687 \\
0.083\end{array}$ \\
\hline $\begin{array}{l}\text { OILIN does } \\
\text { not Granger } \\
\text { Cause LBIND }\end{array}$ & $\begin{array}{l}1.04806 \\
0.3154\end{array}$ & $\begin{array}{l}0.4275 \\
0.6572\end{array}$ & $\begin{array}{l}0.4435 \\
0.7245\end{array}$ & $\begin{array}{l}0.89715 \\
0.4872\end{array}$ & $\begin{array}{l}0.4891 \\
0.779\end{array}$ \\
\hline
\end{tabular}




\begin{tabular}{|c|c|c|c|c|c|}
\hline $\begin{array}{l}\text { LBIND does } \\
\text { not Granger } \\
\text { Cause OILIN }\end{array}$ & $\begin{array}{l}1.53266 \\
0.2268\end{array}$ & $\begin{array}{l}1.6902 \\
0.2066\end{array}$ & $\begin{array}{l}1.23596 \\
0.3229\end{array}$ & $\begin{array}{l}0.91356 \\
0.4785\end{array}$ & $\begin{array}{l}0.83506 \\
0.5462\end{array}$ \\
\hline $\begin{array}{l}\text { OPENESS } \\
\text { does not } \\
\text { Granger } \\
\text { Cause LBIND }\end{array}$ & $\begin{array}{l}4.66183 \\
0.0402\end{array}$ & $\begin{array}{l}1.7920 \\
0.1891\end{array}$ & $\begin{array}{l}1.02098 \\
0.4043\end{array}$ & $\begin{array}{l}0.63162 \\
0.6467\end{array}$ & $\begin{array}{l}0.16061 \\
0.973\end{array}$ \\
\hline $\begin{array}{l}\text { LBIND does } \\
\text { not Granger } \\
\text { Cause } \\
\text { OPENESS }\end{array}$ & $\begin{array}{l}2.50961 \\
0.1252\end{array}$ & $\begin{array}{l}0.0644 \\
0.9377\end{array}$ & $\begin{array}{l}0.20672 \\
0.8905\end{array}$ & $\begin{array}{l}1.82817 \\
0.1699\end{array}$ & $\begin{array}{l}2.16996 \\
0.1164\end{array}$ \\
\hline $\begin{array}{l}\text { OPENESS } \\
\text { does not } \\
\text { Granger } \\
\text { Cause OILIN }\end{array}$ & $\begin{array}{l}1.90065 \\
0.1798\end{array}$ & $\begin{array}{l}1.1384 \\
0.3377\end{array}$ & $\begin{array}{l}0.78231 \\
0.5177\end{array}$ & $\begin{array}{l}0.50069 \\
0.7357\end{array}$ & $\begin{array}{l}0.31821 \\
0.8938\end{array}$ \\
\hline $\begin{array}{l}\text { OILIN does } \\
\text { not Granger } \\
\text { Cause } \\
\text { OPENESS }\end{array}$ & $\begin{array}{l}1.56727 \\
0.2217\end{array}$ & $\begin{array}{l}0.0018 \\
0.9982\end{array}$ & $\begin{array}{l}0.18108 \\
0.908\end{array}$ & $\begin{array}{l}0.28274 \\
0.8851\end{array}$ & $\begin{array}{l}0.44027 \\
0.8132\end{array}$ \\
\hline
\end{tabular}

On the other side, the null hypothesis that GASIN does not Granger Cause OILIN is rejected at the optimal lag criteria except all other criteria. Similarly, INDO does not Granger Cause LBIND at optimal lag while at other lags the optimal condition does not exist. In addition, the null hypothesis that OPENESS does not Granger Cause LBIND are rejected with optimal lag and it is also rejected at lag 2. Thus, there exists a unidirectional causality from Gas consumption to oil consumption, Industrial output to labor force in the industry, openness to labor force in the industry. While no granger causality was found in case of gas consumption and electricity consumption, electricity consumption and industry output, oil consumption and electricity consumption, trade openness and electricity consumption, gas consumption and industry output, labor and gas consumption, gas and trade openness, oil consumption and industry output, oil consumption and labor $\&$ trade openness and oil consumption because of the acceptance of a null hypothesis. However, the bi-directional causality is found between trade openness and industry output due to the rejection of both null 
hypotheses of OPENESS does not Granger Cause INDO and INDO does not Granger Cause OPENESS.

\section{Conclusions and Policy Recommendations}

Energy is a dynamic tool and lifeblood for any economic performance of a country. Though the main objective of the present study was to examine the energy consumption effects on industrial output in Pakistan using annual time series data over the period (1990-2019). For empirical analysis, the ARDL technique has been employed for analyzing the nexus of energy consumption and industrial output. The results reveal that oil consumption is positively and significantly correlated with industrial output. However, gas consumption and electricity consumption have also a positive connection with the industrial output but these are insignificantly connected with industrial output. It may be because of having less efficient means of production or more dependency on foreign resources related to energy instruments. While the other control variables trade openness with other labor, capital connected with industry sector have a positive and significant association with the industrial output in the long run. Results of Granger causality demonstrate that there exists a unidirectional causality from Gas consumption to oil consumption, electricity consumption to industrial output, openness to labor force in the industry and Industrial output to labor force in the industry.

The study suggests that it is needed to focus on the continuous supply of energy for the betterment of industrial sector output so that it can increase the output level of industry progressively. Oil, gas and electricity are contributing a large share in industrial growth so that it would be made an effort to install the plants relevant to these areas to meet the affordable demand in the industry sector.

Electricity is the foremost driver for the progress of industrial output. Officials would focus to concentrate productively on the electricity generation to run the industrial machinery effectively which can stimulate the output level of the industry sector.

There has been observed a continuous decline in gas reliance because of fewer reserves domestically in overall energy mix. Government should focus to facilitate the Gas in industry sector inclusively for the current and future technological framework 
related to the industry which can enhance the industrial sector output as well as economic growth performance in the country.

Oil is the main engine for structural changes in the economy with the progress of the industry sector.

Though it is needed to concentrate on the better use of oil in the industry sector that can be the fruitful element to increase the output level of the industry. It would make an effort to focus on the efficient use of labour-related with industry sector that could improve the performance of output in the industry sector. Likewise, it is also recommended that there is needed to concentrate and invest in capital related to the energy sector which can enhance the industrial output. It is because of the capital of industry that today economies of developed nations are counted in the industrialized world. Further, studies on renewable energy sources can be conducted for the effectual as well as inexpensive utilization of energy in the industry sector that can also enhance the industry sector output either indirect or in an indirect way by stimulating the transmission system and generation capacity progressively. 


\section{References}

1. Abokyi, E., Appiah-Konadu, P., Sikayena, I., \& Oteng-Aba yie, E. F. (2018). Consumption of electricity and industrial growth in the case of Ghana. Journal of Energy, 2018, 1-11.

2. Abid, M., \& Sebri, M. (2012). Energy consumption-economic growth nexus: does the level of a ggregation matter? International Journal of Energy Economics andPolicy, 2(2), 55-62.

3. Akbar, M., Riaz, A., and Hussain, M. T., (2021) Energy Crisis in Pakistan (2008-2018): Impact on Industrial Sector, Global Regional Review, 1(1) 145-153.

4. Alawiye, A. B. (2011). The power sector and industrial development in Nigeria ca se: Power holding company of Nigeria. Ba chelor's Degree Thesis. International Business, Lahti University of Applied Sciences.

5. Akiri, S. E., Ijuo, O. A., \& Apochi, M.P. (2015).Electricity supply and the manufacturing productivity in Nigeria. Journal of Economics and Finance (IOSR-JEF), 6(6), 90-94.

6. Alrajhi, A. N., \& Al-Abdulra zag, B. (2018). The relationship between electricity consumption and economic growth in the Kingdom of Saudi Ara bia. The Journal of Energy and Development, 44(1/2), 299-316.

7. Belloumi, M. (2009), Energy consumption and GDP in Tunisia: Cointegration and causality analysis. Energy Policy, 37, 2745-2753.

8. Biodun, A. A. (2011). The Power Sector and IndustrialDevelopment in Nigeria : Power Holding Company of Nigeria . Lahti: La hti University of Applied Sciences.

9. Chien, F., Sadiq, M., Kamran, H. W., Nawaz, M. A., Hussain, M. S., \& Raza, M. (2021). Co-movement of energy prices and stock market return: environmental wavelet nexus of COVID-19 pandemic from the USA, Europe, and China.Environmental Science and Pollution Research, 1-15.

10. Dada, M. A. (2018). Energy Consumption and Economic Growth Dynamics in Nigeria (1981-2018). The Journal of Energy and Development, 44(1/2), 237-258.

11. Gross, C. (2012). Explaining the (non-) ca usality between energy and economic growth in the US-A multivariate sectoral analysis. Energy Economics, 34(2), 489-499.

12. Han, L. (2019). The Relationship between Energy Consumption Intensity and the Proportion of Industrial Added Value in Jilin Province. Journal of Coastal Research, 93(SI), 582-584.

13. Hamdi, B., Aloui, M., Alqahtani, F., \& Tiwari, A. (2019). Rela tionship between the oil price volatility and sectoral stock markets in oilexporting economies: Evidence from wavelet nonlinear denoised based quantile and Granger-causality a nalysis. Energy Economics, 80, 536552.

14. Hunt, L. C., \& Ninomiya, Y. (2019). Unravelling trend sa nd seasonality: A structural time series analysis of transport oil demand in the UK and Japan. The Energy Journal, 24(3). 
15. Ibrahim, S. S., Mukhtar, S., \& Gani, I. M.(2017). Relationship between electricity consumption, manufacturing output and financial development: A new evidence from Nigeria.Energy Economics Letters, 4(3), 28-35.

16. Kassim, F., \& Isik, A. (2020). Impact of Energy Consumption on IndustrialGrowth in a Transition Economy: Evidence from Nigeria.

17. Li, Z. G., Cheng, H., \& Gu, T. Y. (2019). Research on dynamic relationship between natural gas consumption and economic growth in China. Structural Change and Economic Dynamics, 49, 334-339.

18. Meade, J. E. (1961). A Neoclassical Theory of Economic Growth (London: Allen \& Unwin).

19. Meade, J. E. (2013). Planning and the Price Mechanism (Routledge Revivals): The Liberal-Socialist Solution. Routledge.

20. Maryam, A., \& Bassey, E. M. (2018). Evaluation of the Nigerian industrial sector and economic growth in the face of sustainable development goals. International Journal of Advanced Research in Public Policy, Social Development and Enterprise Studies, 3(1), 49-59.

21. Matei, I. (2017). Is there a Link between Renewable Energy Consumption and Economic Growth? A Dynamic Panel Investigation for the OECD Countries. Revued'economie politique, 127(6), 985-1012.

22. Manyika, J., Lund, S., Chui, M., Bughin, J., Woetzel, J., Batra,P., ... \& Sanghvi, S. (2017). Jobs lost, jobs ga ined: Workforce transitions in a time of a utomation. McKinsey Global Institute, 150.

23. Moeuf, A., Pellerin, R., La mouri, S., Tamayo-Giraldo, S., \& Barbaray, R. (2018). The industrial management of SMEs in the era of Industry 4.0. International Journal of Production Research, 56(3), 1118-1136.

24. Mohsen, A. S. (2015). Linkages between Trade Openness, Capital, Oil Price and Industrial Outputs in Syria.Economic Insights-Trends \& Challenges, 67(3).

25. MTSNO (2015). Economic growth and labor productivity: the experience of the United States, the EU, Brazil and the United Arab Emirates.

26. Na sir, A., Faridi, M.Z., Hussain, H., \& Mehmood, K. A. (2021). Energy Consumption and Bi-Sectoral Output in Pakistan: A Disaggregated Analysis. iRASD Journal of Economics, 3(2), 68-79.

27. Nwajinka,, Akekere, C.C., Yousuo, J., and Purumaziba, O. J. (2013). National Electric Energy Supply and Industrial Productivity in Nigeria from 1970 to 2010 . Journal of economics and sustainable development, 4(14).2013.

28. Nawaz, M. A., Seshadri, U., Kumar, P., Aqdas, R., Patwary, A. K., \& Riaz, M. (2021). Nexus between green finance and climate change mitigation in N-11 and BRICS countries: empirical estimation through difference in differences (DID) approach. Environmental Science and Pollution Research, 28(6), 6504-6519.

29. Nawaz, M. A., Hussain, M. S., Kamran, H. W., Ehsa nullah, S., Maheen, R., \& Shair, F. (2021). Trilemma a ssociation of energy consumption, 


\section{MuhammadUmair, Muhammad Ramzan Sheikh \& KashifSaeed}

carbon emission, and economic growth of BRICS and OECD regions: quantile regression estimation. Environmental Science and Pollution Research, 28(13), 16014-16028.

30. Nwajinka, C.C.A., Yousuo, J., \& John, P. O. (2013). National electric energy supply and industrial productivity in Nigeria from 1970 to 2010. Journal of Economics and Sustainable Development, 4(14), 122129.

31. Olufemi, O. J. (2015). The effects of electricity consumption on industria lgrowth in Nigeria. Energy, 6(13), 54-59.

32. Rastegaripour, F., Karbasi, A., \& Pirmalek, F. (2019). Relationship between $\mathrm{CO} 2$ emissions, energy consumption, and economic growth in Iran. The Journal of Energyand Development, 45(1/2), 197-212.

33. Ramachandra, T. V., Loerincik, Y., \& Shruthi, B. V. (2005). Intra-and inter-country energy intensity trends. The Journal of Energy and Development, 31(1), 43-84.

34. ROMANYUK, I., PSHENICHNIKOVA, S., \& PLOTNIKOV, V. (2019). The relationship of employment, economic growth and economic structure (The example of Russia). Revista ESPACIOS, 40(32).

35. Sineviciene, L., Sotnyk, I., \& Kubatko, O. (2017). Determinants of energy efficiency and energy consumption of Eastern Europe postcommunist economies. Energy \& Environment, 28(8), 870-884.

36. Soytas, U., \& Sari, R. (2003). Energy consumption and GDP: causality relationship in G-7 countries and emerging markets. Energy economics, 25(1), 33-37.

37. Sebri, M., \& Abid, M. (2012). Energy use for economic growth: cointegration and causality analysis from the agriculture sector of Tunisia. Energy Policy, 48, 711-716.

38. Sriyana, J. (2019). Dynamic Effects of Energy Consumption on Economic Growth in an Emerging Economy. International Journal of Energy Economics and Policy, Econjournals, 9(4):pp.283-290.

39. Thoma, M. (2004). Electrical energy usage over the business cycle. Energy Economics, 26(3), 463-485.

40. Tapsin, G. (2017). The link between industry value added a nd electricity consumption. European Scientific Journal, 13(13), 41-56.

41. Tsani, S. Z. (2010). Energy consumption and economic growth: A causality analy sis for Greece. Energy Economics, 32(3), 582-590.

42. Ugwoke, T. I., Dike, C. K., \& Elekwa, P. O. (2016). Electricity consumption and industrial production in Nigeria. Journal of Policy and Development studies, 10(2), 8-19.

43. Yang, H. Y. (2000). A note on the causal rela tionship between energy and GDP in Taiwa n. Energy economics, 22(3), 309-317.

44. Yakubu, Y., Salisu, B. M., \& Umar, B. (2015). Electricity supply and manufacturing output in Nigeria: Autoregressive distributed la g(ARDL) Bound testing approach.Journal of Economics and Sustainable Development, 6(17), 7-19. 
45. Ziramba, E. (2009). Disaggrega te energy consumption and industrial production in South Africa. Energy Policy, 37(6), 22 14-2220.

46. Zamarripa, R., VasquezGalan, B., \& Oladipo, O. (2018). Dynamic modeling of electricity consumption and industrialgrowth in Mexico. The Journal of Energy and Development, 43(1/2), 143-6.

47. Zhu, H., Guo, Y., You, W., \& Xu, Y. (2016). The heterogeneity dependence between crude oil price changes and industry stock market returns in China: Evidence from a quantile regression a pproach. Energy Economics, 55, 30-41.

48. Zhuang, Y., Yang, S., Chupradit, S., Nawaz, M. A., Xiong, R., \& Koksal, C. (2021). A nexus between macroeconomic dynamics and trade openness: moderating role of institutional quality. Business Process ManagementJournal. 